\title{
37. ORIGIN OF SEGREGATION VESICLES IN VOLCANIC ROCKS FROM THE LAU BASIN, LEG $135^{1}$
}

\author{
Sherman H. Bloomer ${ }^{2}$
}

\begin{abstract}
Concentrations of dark-colored, highly vesicular, quench-textured mesostasis occur commonly in volcanic rocks drilled in the $\mathrm{Lau}$ Basin during Leg 135. These segregations occur as veins, patches, and vesicle linings in rocks with $49 \%-54 \% \mathrm{SiO}_{2}$. The segregations are depleted in $\mathrm{Mg}, \mathrm{Ca}, \mathrm{Al}, \mathrm{Sc}, \mathrm{Ni}$, and $\mathrm{Cr}$ and enriched in $\mathrm{Ti}, \mathrm{Ba}, \mathrm{Y}$, and $\mathrm{Zr}$ compared to the groundmass with which they occur. Many of the segregations are unusually enriched in copper. The elemental variations show that the segregations are residual liquids produced by $12 \%-55 \%$ crystallization of plagioclase and clinopyroxene, with minor olivine, opaques, or orthopyroxene from the groundmass melt. The liquids forming the segregations are mobilized and emplaced in earlier formed vesicles during the rapid crystallization of the groundmass. The dominant process in this mobilization and emplacement is volatile exsolution from crystallizing melts constrained by a rigid crystalline framework. This exsolution produces significant overpressures within the late-stage melts; the overpressure drives the residual melts through the walls of the older vesicles, along planes of weakness, and into voids. This mechanism is consistent with the occurrence of bimodal vesicle populations in many of the host lavas.
\end{abstract}

\section{INTRODUCTION}

Concentrations of dark-colored, aphyric, highly vesicular, quenchtextured material occur as veins, vesicle linings, and patchy segregations in many of the volcanic rocks recovered from the Lau Basin during Ocean Drilling Program (ODP) Leg 135. Similar material has been described from a number of basalt suites. Smith (1968) made a detailed study of the textures of such material lining and filling vesicles in Ordovician basalts in New South Wales, Australia. He termed these segregation vesicles and interpreted them as mesostasis injected into earlier formed vesicles. Identical segregation vesicles occur in basalts from Deep Sea Drilling Project (DSDP) Leg 37 (Baragar et al., 1977), DSDP Leg 46 (Sato, 1978), ODP Leg 106 (Shipboard Scientific Party, 1988), ODP Leg 126 (Shipboard Scientific Party, 1990), and the Oceanographer Fracture Zone (Shibata et al., 1979). Microprobe analyses of the Leg 46 segregations suggested that they were indeed residues from the crystallizing groundmass (Sato, 1978). Similar quench material has also been noted as "segregation veins" (Kuno, 1965; Kuno et al., 1957). Segregation vesicles, veins, and patches are ubiquitous in backarc basalts from both the Lau Basin and the Mariana Trough (J. Hawkins, pers. comm., 1992).

Various explanations have been put forward for the origin of the segregations. Smith (1968) argued that thermal contraction alone did not produce a sufficient pressure gradient to inject mesostasis into vesicles, and that an additional external pressure was required. $\mathrm{He}$ considered that the movement of a basaltic flow into deeper water might provide the requisite additional pressure. Smith (1968), however, only considered cooling from liquidus to solidus temperatures: extreme undercooling due to eruption in seawater might produce sufficient thermal contraction to allow vesicles to implode and fill with mesostasis (J. Natland, pers. comm., 1993). Anderson et al. (1984) examined the textural and chemical evidence bearing on the origin of segregation vesicles and concluded that they were residual liquids forced into earlier formed vesicles by a pressure gradient that developed as a result of the concentration of $\mathrm{H}_{2} \mathrm{O}$ into the residual liquid and gas. Other explanations discussed on board ship for the origin of the segregations included liquid immiscibility or mixing of multiple magmas. Differential movement and shear within flows may also contribute to the concentration of the segregation liquids.

\footnotetext{
' Hawkins, J., Parson. L., Allan. J.. et al.. 1994. Proc. ODP. Sci. Results. 135: College Station, TX (Ocean Drilling Program).

${ }^{2}$ Department of Geology, Boston University, Boston, MA 02215, U.S.A.
}

These segregations are very common in the Leg 135 samples; their abundance indicates an efficient mechanism of concentrating and transporting late-stage liquids. I present here the results of a detailed geochemical study of these segregations and of their host lavas and suggest a mechanism for their development.

\section{DESCRIPTION}

The segregations occur in basalt and basaltic andesite flows and sills from Sites 834 (Units 2, 6-7, 9-10, and 12-13), 835 (Unit 1), 836 (Units 3-4), 837 (Unit 1), and 839 (Units $1-4$ and 9). Their most common form is as linings and fillings in large (1-6 mm), elliptical to circular vesicles, identical to Smith's (1968) segregation vesicles (Fig. 1). Plagioclase microlites occur tangential to the exterior of some of these large, filled vesicles. The dark segregations also occur as thin veins (Fig. 1) and as irregular, patchy concentrations.

The segregations (as I will hereafter refer to them), regardless of form, are very dark colored and aphyric, and they are more highly vesicular than their host lavas. The host lavas have from $10 \%$ to $30 \%$ vesicles. The segregations are $60 \%-80 \%$ vesicles, with the remainder composed of quench-textured plagioclase and clinopyroxene crystallites, abundant small opaque grains (which produce the dark color), and mesostasis (Parson, Hawkins, Allan, et al., 1992). The groundmass around the segregations typically has plagioclase and clinopyroxene microlites (with olivine, opaques, or orthopyroxene microlites, depending upon the rock composition) and $25 \%-65 \%$ mesostasis. Segregations with similar textures occur in rocks ranging from $49 \% \mathrm{SiO}_{2}$ and $15 \% \mathrm{MgO}$ to $54 \% \mathrm{SiO}_{2}$ and $4.5 \% \mathrm{MgO}$.

\section{METHODS}

Samples representative of each type of segregation (vesicles, veins, and patches) were selected and the segregations drilled out with fine-point carbide drill bits in a small drill press. If the segregations were small, several were combined to give an adequate-sized sample. Sample sizes ranged from 0.002 to $0.25 \mathrm{~g}$. Two different segregations from Sample 135-839B-3R-1, 71-76 cm, and four segregations from Sample 135-834B-16R-1, 107-111 cm, were sampled separately to assess the within-sample homogeneity.

Groundmass pieces, free of segregations, from the same samples were crushed in an diamonite mortar to $0.5-2 \mathrm{~mm}$ fragments. These fragments were picked to yield separates as free from alteration and of phenocrysts or microphenocrysts as possible. However, highly 

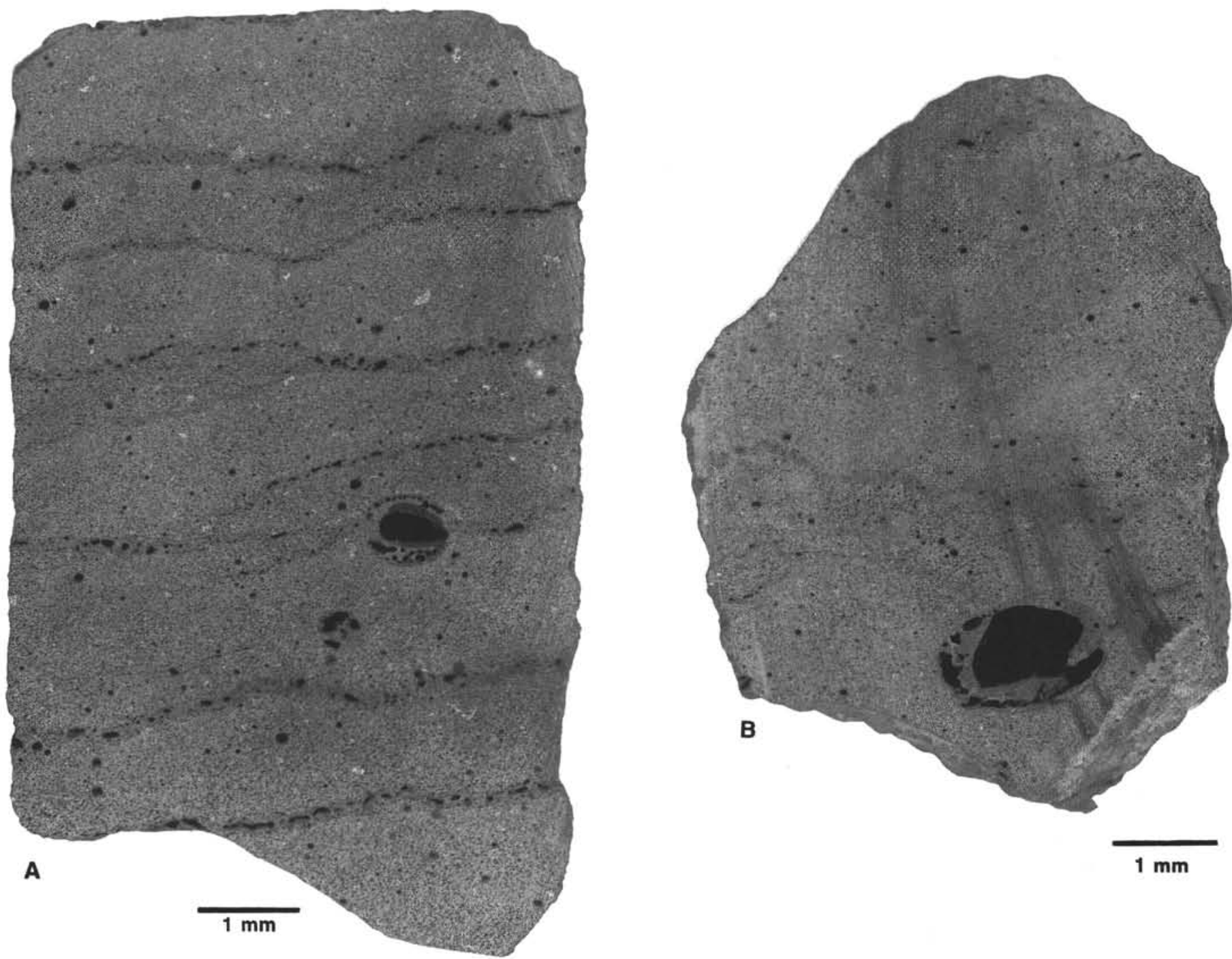

$1 \mathrm{~mm}$

Figure 1. A. Example of segregation veins and vesicles in a basaltic andesite (Sample 135-837B-2R-1, 111.5-122 cm, Piece 17). B. Large segregation vesicles; note the margins of the preexisting ellipsoidal vesicle (Sample 135-837B-4R-1, 42-50 cm, Piece 8).

altered samples and densely microphyric samples could not be completely cleaned. Groundmass sample sizes were $0.1-2.0 \mathrm{~g}$.

Segregation samples were powdered as they were drilled; groundmass samples were powdered in a diamonite mortar. Samples were dried at $110^{\circ} \mathrm{C}$, and aliquots ranging from 0.002 to $0.250 \mathrm{~g}$ were mixed with lithium metaborate flux. Flux to sample ratios were $3: 1$ when possible, but no less than $0.02 \mathrm{~g}$ of flux were used with any sample. The mixtures were fused at $1000^{\circ} \mathrm{C}$ for $20 \mathrm{~min}$, and dissolved in $12-50 \mathrm{~mL}$ of $10 \% \mathrm{HNO}_{3}$. These solutions were used for trace element analyses; 1 - $\mathrm{mL}$ aliquots of these solutions were diluted in $25 \mathrm{~mL}$ of $10 \% \mathrm{HNO}_{3}$ spiked with $\mathrm{LiCO}_{3}$ as a matrix modifier for major element analyses.

The samples were analyzed for major and trace elements by inductively coupled plasma emission spectrometry using a JY-24 scanning spectrometer. Standardization used similarly prepared USGS reference materials and aqueous standards. Precision is $0.3 \mathrm{wt} \%$ for $\mathrm{SiO}_{2},<0.1$ wt $\%$ for other oxides, and $<1.5 \mathrm{ppm}$ for all trace elements except for zinc, which is precise to $5 \mathrm{ppm}$. Details of precision and accuracy for the technique are included in Bloomer et al. (this volume).

The second smallest sample analyzed (135-839B-23R-1, 46-50 $\mathrm{cm}$ ) yielded a $90 \%$ sum, probably as a result of a weighing error; this value was normalized to $100 \%$ for comparison with its groundmass. The smallest segregation analyzed, from Sample 135-837B-2R-1, $2-7 \mathrm{~cm}$, yielded a sum less than $85 \%$ and was discarded.
The analyses presented in Table 1 are of unignited samples; loss on ignition (LOI) was not determined because of the small sample size. The totals on the analyses indicate that volatile contents in the groundmass range from $0.5-2.3 \mathrm{wt} \%$. Totals for the segregation analyses show a similar range of volatile contents, though their small sample size makes the analytical totals less precise than those for the groundmass. The modal analyses included in Table 1 are from Parson, Hawkins, Allan, et al. (1992); the modes are for unit averages or for the nearest point-counted sample to the analyzed sample.

\section{RESULTS}

The chemical compositions of the segregations are shown in Figure 2, normalized to the composition of the groundmass in which they occur. The segregations, regardless of the form in which they occur or the composition of their host, exhibit similar elemental trends. The segregations are typically depleted in $\mathrm{Al}, \mathrm{Ca}, \mathrm{Mg}, \mathrm{Sc}, \mathrm{Ni}$, and $\mathrm{Cr}$ and enriched in $\mathrm{Na}, \mathrm{Ti}, \mathrm{Fe}$, and incompatible trace elements, relative to the groundmass compositions (Fig. 2). Sr and Si tend to remain constant from host to segregation. Elements more susceptible to low-temperature alteration, such as $\mathrm{K}, \mathrm{Ba}$, and $\mathrm{P}$, show some irregular enrichments or depletions (Fig. 2). Cu, in many samples, is enriched relative to similarly incompatible elements (Fig. 2). 


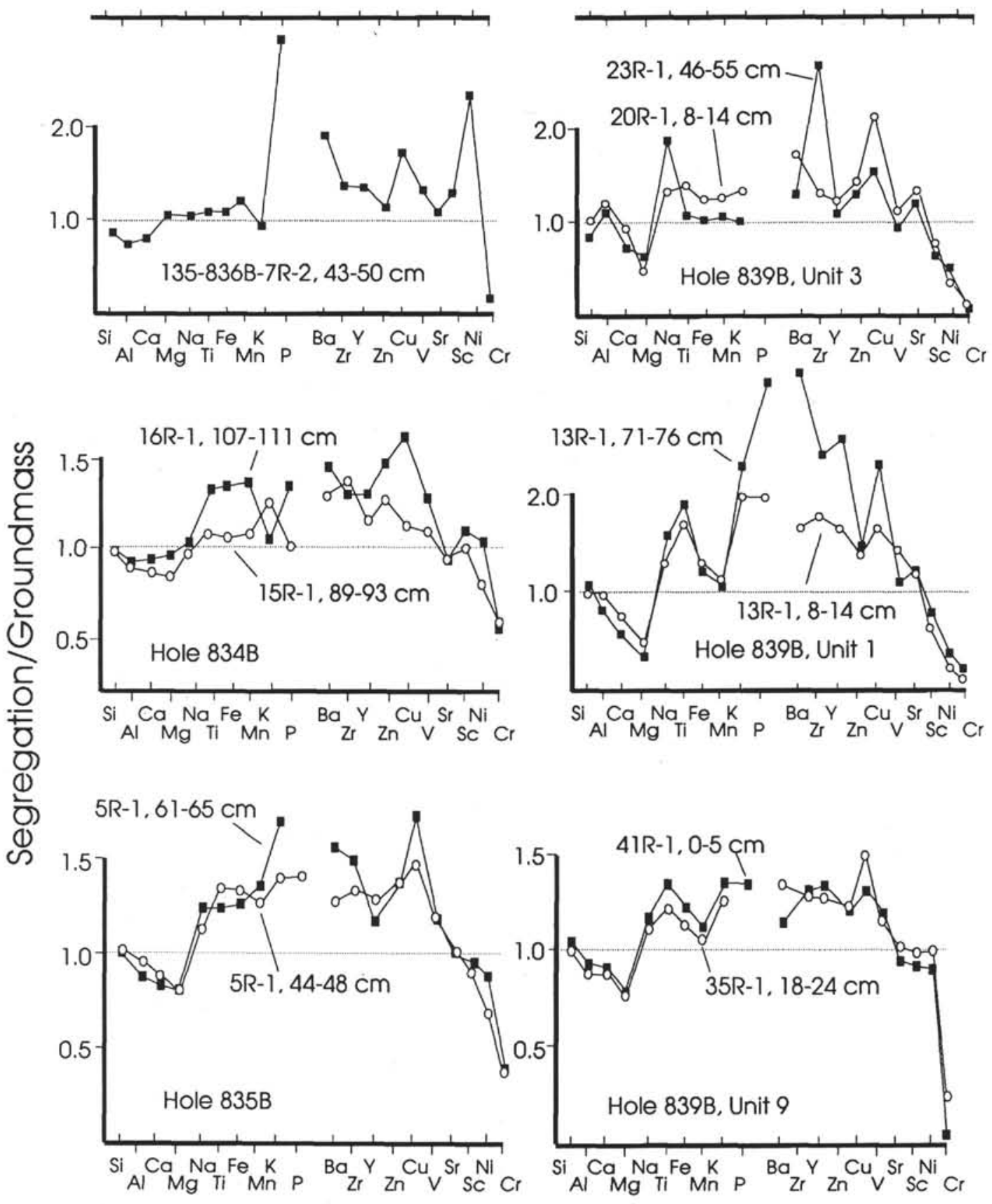

Figure 2. Compositions of segregations plotted normalized to the compositions of the associated groundmass. Phosphorus was not determined on all samples. Data from Table 1.

Segregations within individual samples are relatively homogeneous (Table 1). Segregations from the same sample vary in composition by less than $10 \%$, except for $\mathrm{Ni}$ and some of the more alterationsensitive elements (Table 1). The segregations have incompatible element ratios similar or identical to the associated groundmass (Fig. 3).

The elemental patterns and element ratios are consistent with Smith's (1968) and Anderson et al.'s (1984) hypotheses that the segregations are aggregates of residual liquids formed during the crystallization of the groundmass. The consistent element trends and ratios argue against an origin by mixing of different magmas, and the segregations do not have the low-Si, high-Fe compositions of immiscible silicate liquids (Philpotts, 1982). The segregations are simply concentrations of the mesostasis. The evolution of the segregations can be modeled by simple equilibrium crystallization (Fig. 4) of various amounts of plagioclase and clinopyroxene, with lesser amounts of olivine and orthopyroxene, or an Fe-Ti opaque phase depending upon the bulk rock composition (Table 1). Least-squares solutions require $12 \%-$ $55 \%$ crystallization, with mineral proportions varying from 20:5:1 plagioclase (PLAG):clinopyroxene (CPX):olivine (OL) to 11:2:5 PLAG: CPX:orthopyroxene (OPX). A crude correlation exists between the calculated fraction of liquid remaining and the modal \% mesostasis in the samples $\left(\Sigma R^{2}=0.73\right)$. Furthermore, the calculated fractionated mineral assemblages are similar to the modal phenocryst and microphenocryst abundances; both observations show that the models are physically reasonable.

The calculated derivative compositions are not an exact match for the segregation compositions. The crystallization of the groundmass is clearly rapid and likely to produce some disequilibrium compositions; 
Table 1. Chemical compositions of segregations (labeled fill) and groundmass separates (labeled matrix).

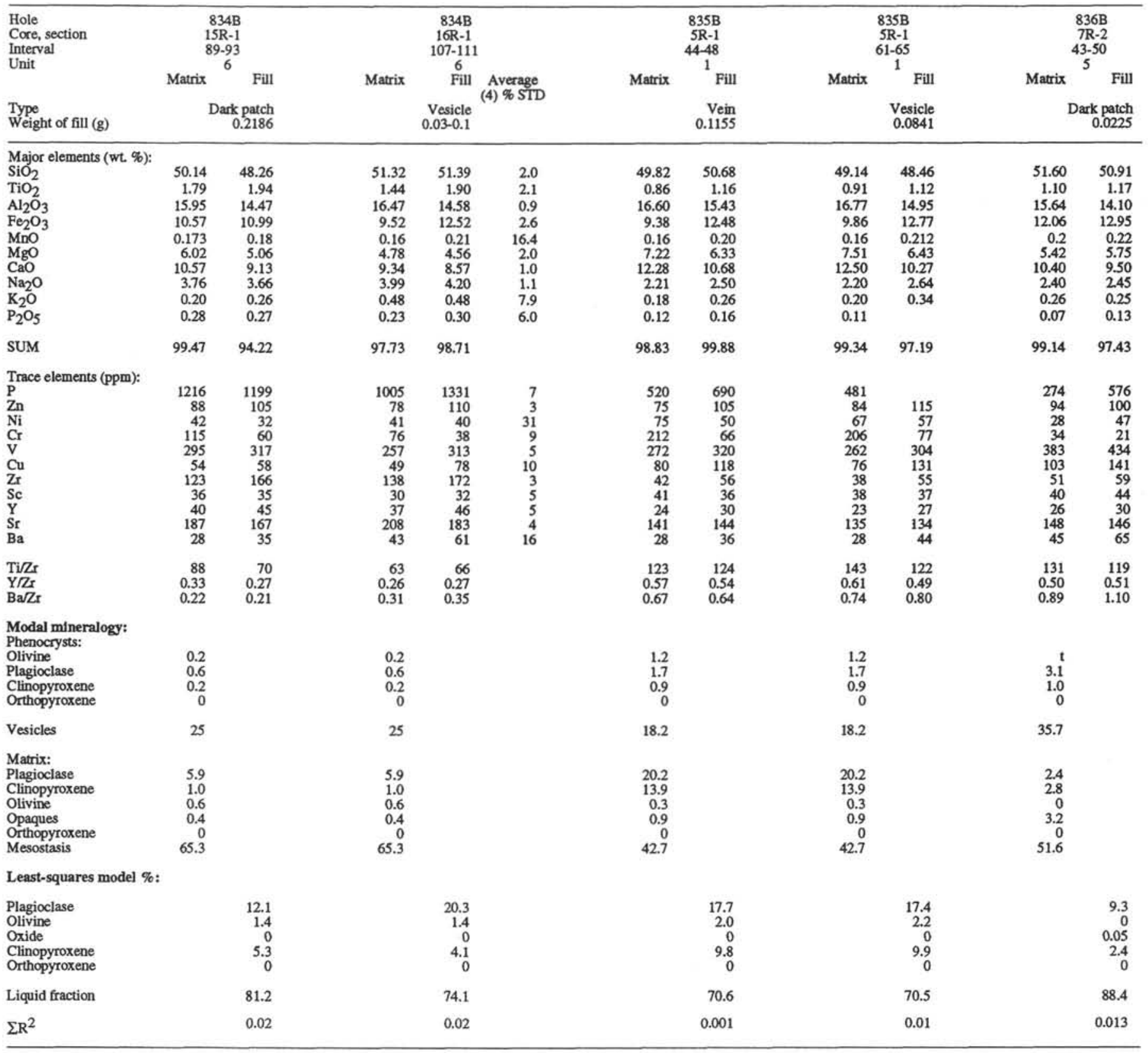

Notes: Oxides in weight percent (wt \%). elements in parts per million (ppm). Modal mineralogy from shipboard point counts of the corresponding units (Parson. Hawkins. Allan. et al., 1992). Least-squares models are for production of the fill by crystallization of the matrix. Averages and $\%$ standard deviations are given for samples in which more than one segregation was analyzed. Triple asterisks (***) indicate that the fill analysis was normalized to $100 \%$ (from an initial sum of $90.37 \%$ ). Phosphorus could not be determined for all samples because of the large sample dilutions.

the models have only been calculated using generic mineral compositions and distribution coefficients. However, despite the rapid crystallization, most of the groundmass and segregation compositions plot near anhydrous 1-atm. tholeiitic cotectics (Fig. 5), suggesting a nearequilibrium evolution of the segregations. This is in contrast to the results of Sato (1978), who found markedly disequilibrium compositions in the segregation vesicles he examined.

Alteration has clearly perturbed some of the elemental abundances (see $\mathrm{K}$ in Fig. 4). A notable feature is that $\mathrm{Cu}$ is typically more enriched in the segregations than are even the most incompatible elements (e.g., $\mathrm{Zr}$ ). These enrichments likely result from the incorporation of sulfides lining the original vesicle walls (cf. Yeats and Mathez, 1976) into the segregation fillings during their injection or by mixing when the fillings were drilled from the rocks.

\section{DISCUSSION}

The bulk chemical compositions of the segregations, and their similarity to calculated fractional crystallization products, show that they are residual liquids produced during the crystallization of the groundmass, as concluded by Smith (1968) on textural evidence. Regardless of the bulk composition of their host, or whether they occur as veins, patches, or vesicle fill, all of the segregations appear to have a common origin. 
Table 1 (continued).

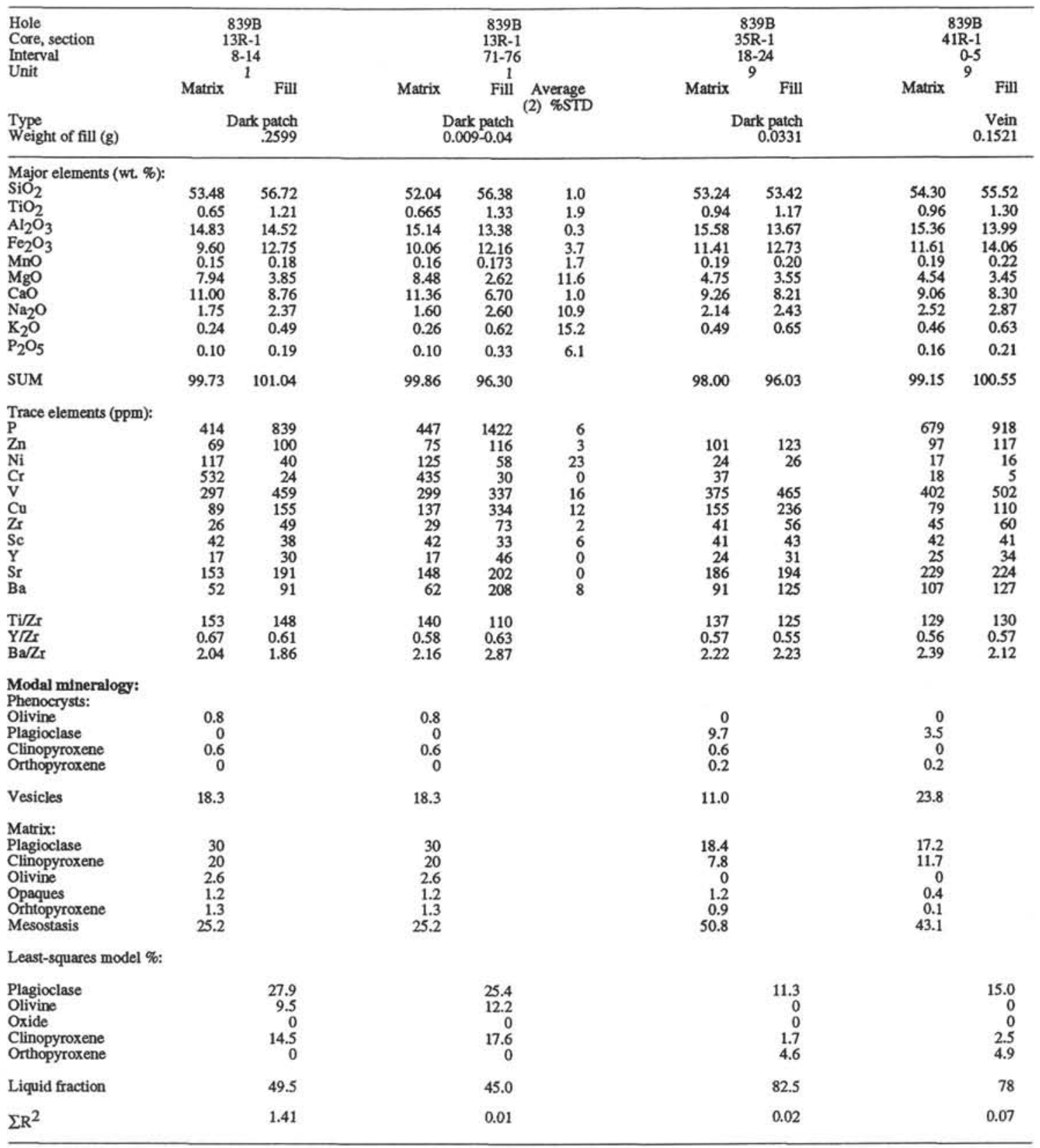

Smith (1968) recognized that a mechanism was required to concentrate these liquids and to inject them into earlier formed vesicles. The vesicles filled by the segregations clearly formed before the crystallization of the groundmass, as plagioclase microlites occur tangential to their boundaries, and before the injection of the segregation material, as the original boundary of the vesicles are always clearly discernible (Smith, 1968; Fig. 1).

The problem in understanding these segregations lies in identifying a mechanism that will concentrate and mobilize the residual liquids. Deformation of the lava flows is one possibility. Gabbros from Hole $735 \mathrm{~B}$ on the Southwest Indian Ridge show clear evidence of the mobilization of late-stage liquids from a semirigid crystal framework into ductile shear zones (Bloomer et al., 1991). A similar process might operate, on a smaller scale, during crystallization of a basaltic flow that continued to move as it developed a rigid, internal crystal framework. Such a mechanism could produce the segregation veins and patches.
However, it is less likely that such a mechanism could fill earlier formed vesicles and little evidence (such as flattened vesicles or trachytic textures) exists for much syn- or post-crystallization flow in the Leg 135 samples.

Smith (1968) suggested that segregation vesicles might develop as a result of an increase in external pressure during crystallization; the increased pressure would filter press the residual liquid from the groundmass into the vesicles. He suggested that such an increase of pressure would develop as a flow moved downslope from shallow to deep water. Sato (1978) pointed out that it is difficult to invoke such a mechanism for segregations developed in flows on the deep-ocean floor, where the pressure differences during eruption should be relatively small.

Two other processes have been suggested that would develop pressure gradients within lava flows that in turn could lead to the development of segregation veins and vesicles. The first invokes the con- 
Table 1 (continued).

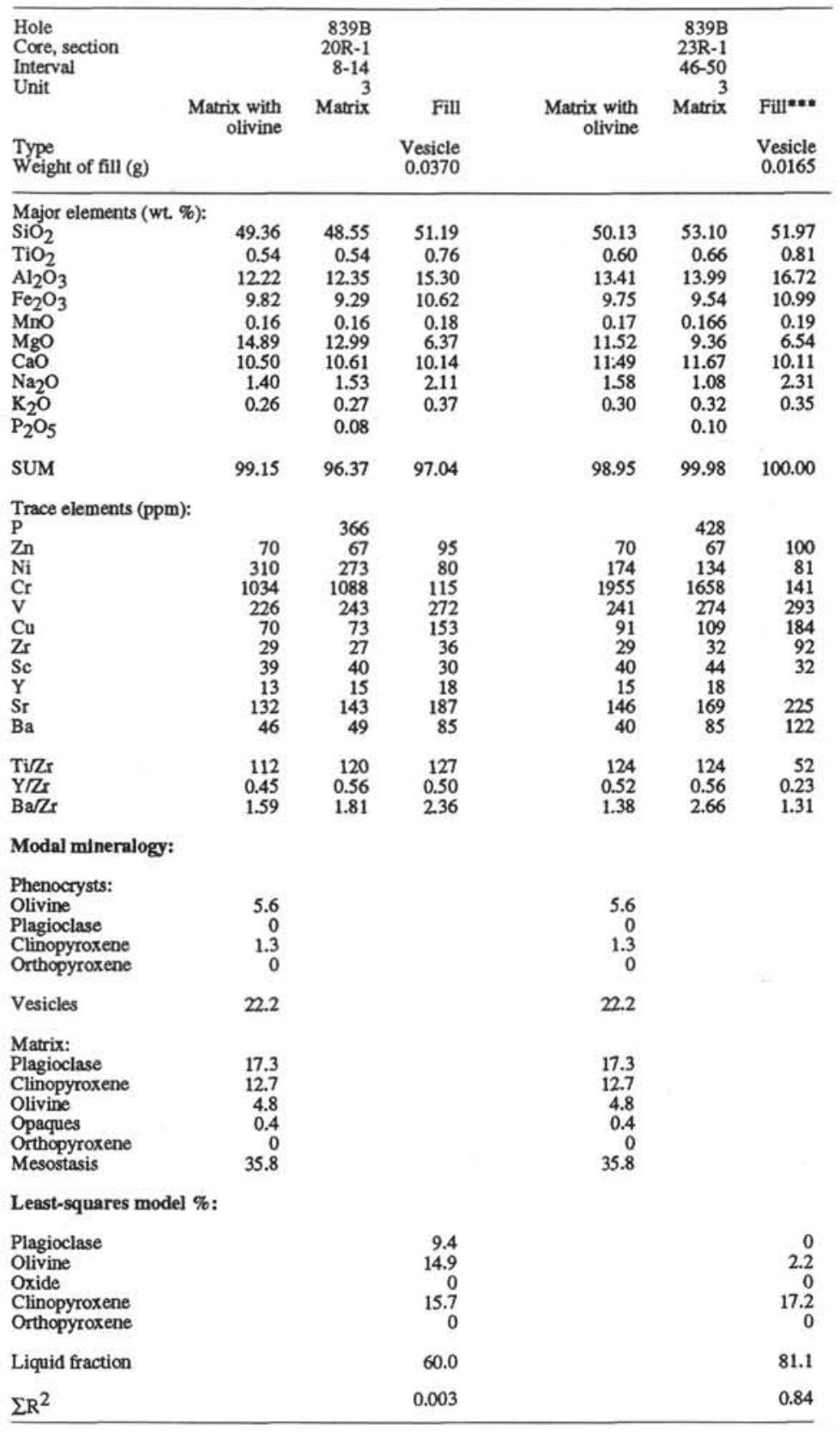

traction of pre-eruption vesicles as the flow is suddenly undercooled upon eruption into seawater; the vesicles are postulated to implode and draw in mesostasis as a consequence of the undercooling (Smith, 1968; J. Natland, pers. comm., 1993). The second mechanism recognizes that during groundmass crystallization dissolved volatiles are concentrated into a diminishing volume of melt, creating higher gas pressures in the mesostasis than in the earlier formed vesicles (Anderson et al., 1984).

Smith (1968) considered the creation of segregation vesicles by the contraction of vesicles during cooling, and the consequent filling of the vacated volume by interstitial material sucked into the vesicle. He rejected this mechanism because the degree of contraction from liquidus to solidus temperatures was insufficient to draw in the volume of interstitial material seen filling the vesicles. The segregation vesicles not uncommonly fill $50 \%-80 \%$ of the larger vesicles (Fig. 1; Smith, 1968) while cooling from $1250^{\circ}$ to $1000^{\circ} \mathrm{C}$ would only provide for filling $20 \%$ of the original vesicle volume. A $50 \%$ reduction in volume requires cooling to $625^{\circ} \mathrm{C}$, a reduction of $80 \%$ volume cooling to $250^{\circ} \mathrm{C}$ (assuming ideal gas behavior). J. Natland (pers. comm., 1993) has correctly pointed out that submarine lava flows undergo tremendous undercoolings at their interface with cold seawater; this undercooling may indeed produce sufficient vesicle contraction in the outer rinds of flows to produce segregation vesicles. However, many of the segregations described here occur in more crystalline interiors of flows. Segregation vesicles developed because of thermal contraction should be distributed irregularly throughout the flow (in places where fractures allowed substantial undercooling), they should be expected to develop early in the cooling of the flow (i.e. the mesostasis should not show large degrees of near-equilibrium fractionation), and they should be concentrated principally in large vesicles, not in veins. However, the segregations in the Lau Basin basalts occur in both veins and vesicles, they are usually distributed regularly throughout indi- 


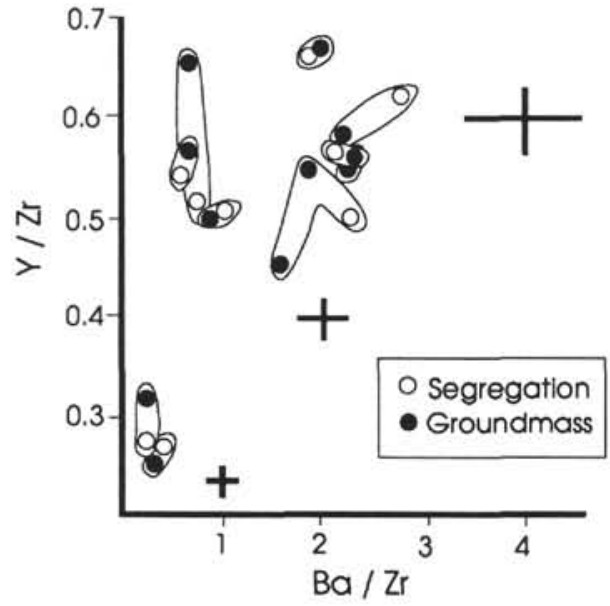

Figure 3. Incompatible element ratios for segregation-groundmass pairs. Error bars are estimates of the within-sample variability of the segregations, based on percentage variations between analyses of different segregations in single samples (Table 1). vidual flows, and they are of consistent composition within individual flows; that is, they form after $20 \%-60 \%$ of near-equilibrium crystallization, indicating slower cooling than implied by undercooling of $400-800^{\circ} \mathrm{C}$. This is consistent with observations on cooling rates within pillow flows. Observations of flows off Hawaii show that the pillow flows retain molten interiors within cooled glassy shells. Estimates of cooling rates of basalts at Serocki Volcano on the MidAtlantic Ridge are $1{ }^{\circ} \mathrm{C} / \mathrm{hr}, 48 \mathrm{~cm}$ from the glassy margin, and 0.03 $0.4^{\circ} \mathrm{C} / \mathrm{hr}, 300 \mathrm{~cm}$ from the rind (Grove, 1990). It does not seem likely that extreme undercooling is an adequate mechanism to produce the segregation veins and vesicles seen in the Lau Basin volcanics.

Anderson et al. (1984) have pointed out that it is possible to develop substantial internal pressure gradients during crystallization of volatile-rich melts. As the mesostasis crystallizes, the volatiles within the melt are concentrated into a diminishing volume of melt that rapidly becomes vapor saturated. This saturation requires the creation of new vesicles, or the growth of existing vesicles (i.e., an increase in vesicle volume) (MacPherson, 1984). If the flow becomes sufficiently rigid that the required additional volume cannot be created, overpressures develop within the mesostasis that are capable of forcing melt into earlier formed vesicles. Anderson et al. (1984) observed piercing points on the walls of large vesicles, through which the interstitial melt
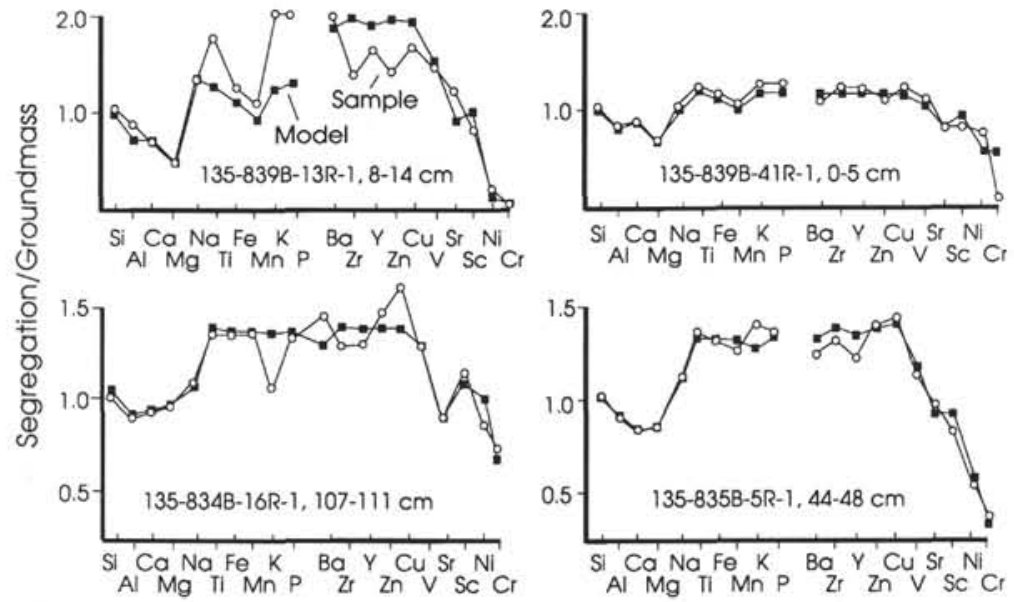

Figure 4. Model compositions of segregations calculated by simple crystal fractionation of the groundmass compared with actual segregation compositions. Major element models were calculated by linear leastsquares mixing (results in Table 1). The resulting mineral assemblages were used to calculate trace element concentrations in residual liquids by simple Rayleigh fractionation using partition coefficients from Allegré et al. (1977) and Philpotts (1990). Sample 135-839B-13R-1, 8-14 cm, yielded the worst fit of any segregation; the overall pattern calculated is, however, very similar to that in the sample. Note the enrichment in $\mathrm{Cu}$ in several of the samples over that predicted by equilibrium fractionation.

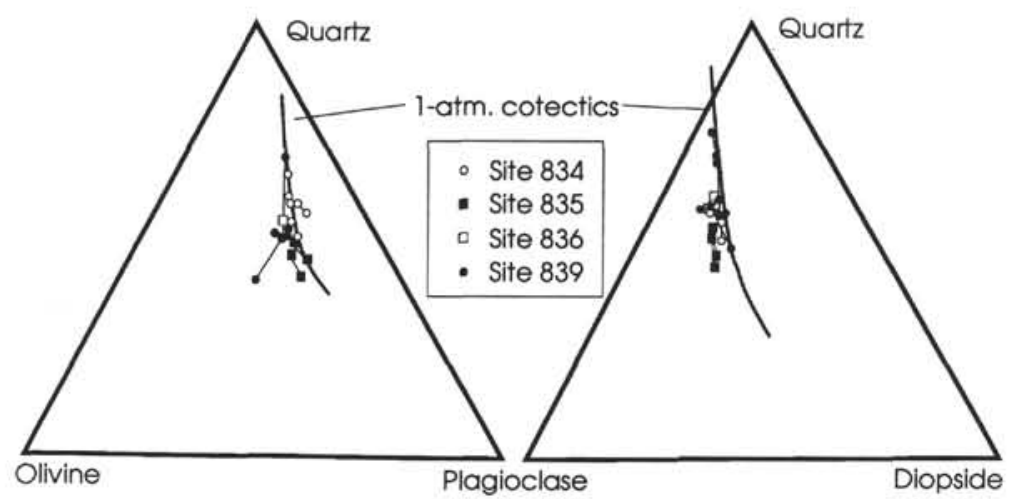

Figure 5. Segregation and groundmass samples plotted in CMAS projections from clinopyroxene (left) and from olivine (right); molar projections after Elthon (1983). Also shown are 1-atm. cotectics for oceanic tholeiitic basalts. 

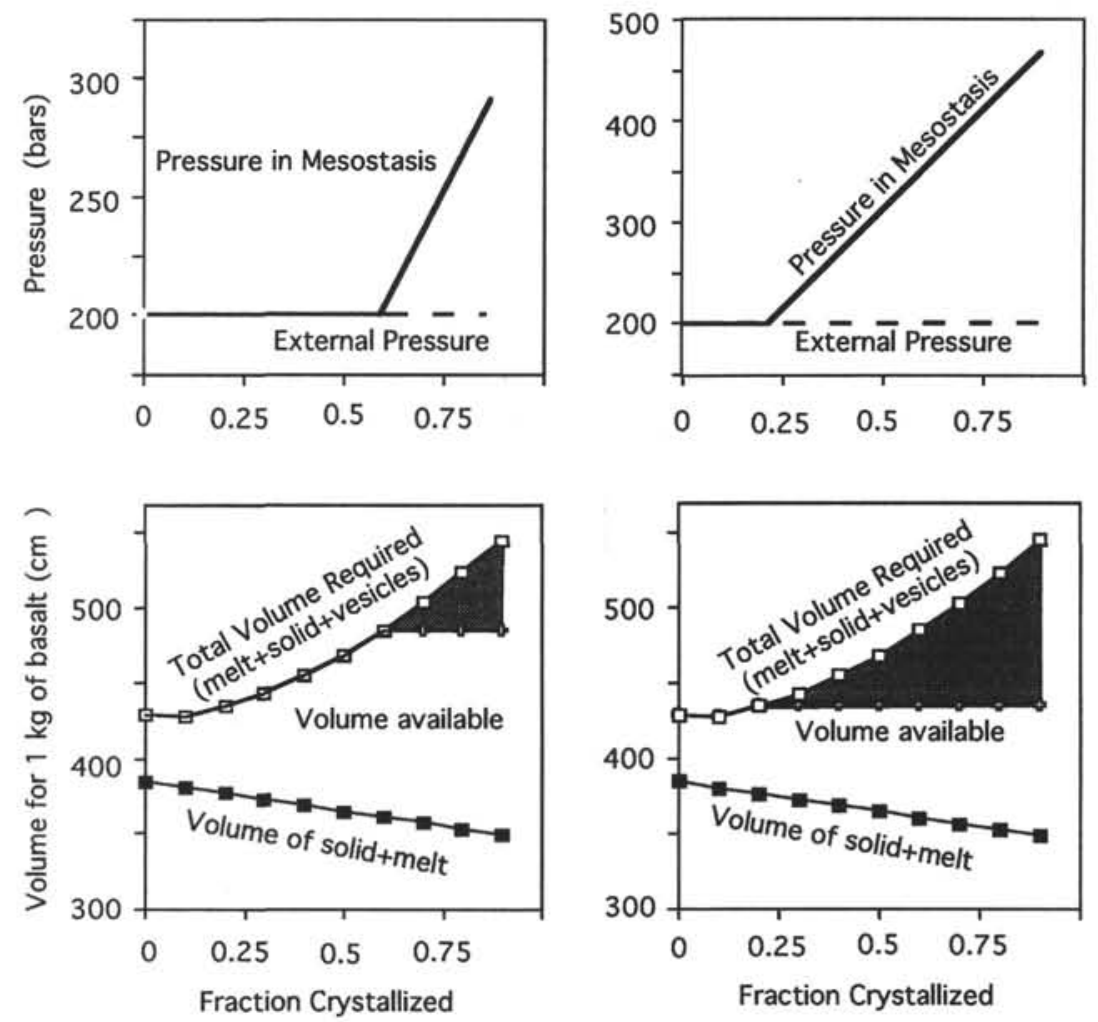

Figure 6. Model for the production of segregation vesicles, as discussed in the text. Bottom graphs show volume occupied by different portions of the crystallizing basaltic magma; top graphs show the pressure in the mesostasis and the pressure in the large, early formed vesicles (which is assumed to be ambient pressure). Left-hand plots assume that the flow initially expands as it crystallizes and degasses and then that its volume becomes fixed after $60 \%$ crystallization. The right-hand plots assume that the flow's volume becomes fixed after $20 \%$ crystallization. The shaded areas indicate the volume deficit between that available and that required at the ambient pressure; this is the region within which overpressures will develop in the mesostasis if the flow volume is fixed. Once the volume becomes fixed, the gas pressure in the mesostasis rapidly becomes greater than the pressure in the large, early formed vesicles and the potential exists for the mesostasis to pierce the walls of the vesicles.

appears to have flowed, and they demonstrated that the viscosity and porosity of the flows they examined were consistent with this mechanism for the formation of the segregations.

An example of this process is illustrated in Figure 6, assuming a basaltic melt that has $1 \mathrm{wt} \%$ dissolved $\mathrm{H}_{2} \mathrm{O}$. Studies of backarc basalts indicate that most of their volatile content is water (e.g., Garcia et al., 1979), but the argument is independent of the composition of the volatiles. I have assumed that the basalt erupts at a temperature of $1250^{\circ} \mathrm{C}$, at a water depth equivalent to a pressure of 200 bars, where the solubility of $\mathrm{H}_{2} \mathrm{O}$ in the melt is $0.85 \%$. The magma is presumed to erupt on the seafloor with $0.15 \%$ water exsolved as large vesicles formed during ascent to the surface. These early formed vesicles are presumed to equilibrate at ambient pressure (Sarda and Graham, 1990). The melt density is taken at $2.6 \mathrm{~g} / \mathrm{cm}^{3}$, the density of the crystalline solid as 2.9 $\mathrm{g} / \mathrm{cm}^{3}$, and the solidus temperature $1000^{\circ} \mathrm{C}$. The solubility of water in the melt is presumed to increase linearly from $0.85 \%$ initially to $1.44 \%$ at the solidus. The curves in Figure 6 are volumes calculated for $1 \mathrm{~kg}$ of basaltic melt.

The basalt, because it becomes oversaturated in water as it ascends to the surface, will exsolve $0.15 \%$ of its water as vesicles before eruption. The volume occupied by the magma will be the sum of the vesicle volume (calculated assuming a perfect gas) and the melt volume. As the melt begins to crystallize, the volume occupied by the magma will change. The crystalline solid occupies less volume than its corresponding melt, so the volume of melt plus solid will decrease slowly. However, as the volume of melt decreases during crystallization, the remaining water is concentrated in that melt. The remaining melt rapidly becomes oversaturated in water and exsolves new vesicles and enlarges the existing vesicles. This additional gas volume grows rapidly, such that the total volume required (assuming the external pressure remains constant) by melt plus solid plus vesicles increases during crystallization (Fig. 6). This occurs even taking into account the thermal contraction of the vesicles during cooling. The required increase in volume can be accommodated as long as the flow can expand vertically or horizontally. However, at some point it is likely that the flow will become sufficiently crystalline that its volume will be limited by a rigid crystal framework. At this point, continued crystallization produces additional vesiculation in the residual liquids, but the vesicles cannot expand to their equilibrium volume as the total volume available to the flow is fixed. The internal pressure in the vesicles must therefore increase to compensate for the reduced volume. Once the volume of the flow becomes fixed, these overpressures develop rapidly and will quickly exceed the pressure within the larger, earlier formed vesicles. Once the volatile pressure in the mesostasis exceeds the combination of the pressure in the larger vesicles and a small contribution from the surface tension of the vesicle, the walls 
of a large vesicle can be breached and the mesostasis forced into the vesicle by the overpressure. These vesicle-driven overpressures can also force mesostasis into voids or planes of weakness within the sample, producing patches and veins of segregations.

These calculations assume that none of the exsolving volatiles escape out of the flow. Clearly, this is not realistic; however, given the rapid rate at which overpressures develop (Fig. 6), only a small amount of the excess gas need be trapped in the mesostasis to produce overpressures. A number of textural features in the Lau Basin volcanic rocks are present that are consistent with the process outlined above. The segregations are commonly much more vesicular than the groundmass in which they are developed, suggesting very high volatile concentrations when they were emplaced. The samples with segregations typically have bimodal vesicle populations: one of several large $(>0.5 \mathrm{~mm})$ vesicles, which may have segregation fillings, and a more abundant population of small vesicles $(<0.1 \mathrm{~mm})$. The size and abundance of the latter population indicate a rapid cooling and degassing (Dick, 1980). Finally, the percentage of mesostasis in samples with segregations averages $45 \%$; this is about the point at which the crystal framework should become semirigid (Bloomer et al., 1991). However, the point at which the mesostasis injection occurred may vary from flow to flow. The model calculations indicate that it occurred at $20 \%-60 \%$ crystallization in different samples; what may determine the point at which overpressures develop may not be when the flow becomes internally rigid, but when it develops an external, rigid shell. The local development of the segregations must also require a sufficient crystal density that the overpressures in the mesostasis are distributed irregularly around the larger vesicles. If a vesicle were surrounded only by interstitial melt, the pressure distribution around the vesicle would be isotropic and would simply produce a contraction of the larger vesicle.

The development of the segregations depends on cooling rates, original volatile content, melt density, viscosity of the interstitial melt, permeability of the crystallizing flow, and the diffusivity of volatiles through the flow, which is probably related to flow thickness. The abundance of segregations in backarc basalts is likely linked to the higher volatile abundances of backarc basalts relative to normal MORB (Garcia et al., 1979). Their common occurrence in backarc basalts suggests that late-stage mobilization of residual liquids may be an important process in backarc lavas. The unusual enrichments in $\mathrm{Cu}$ in many of the segregations shows that they may concentrate some elements over the level expected during slower, purely equilibrium crystallization. These segregations may be important loci for the later remobilization of metals during hydrothermal alteration of the crust.

\section{SUMMARY}

The bulk chemical compositions of segregations in volcanic rocks from Leg 135 show that they are residual liquids produced during the crystallization of the groundmass, as concluded by Smith (1968) on textural evidence. Their origin appears the same regardless of the bulk composition of their host, or whether they occur as veins, patches, or vesicle fill. The segregations form by $12 \%-55 \%$ crystallization of the groundmass at near-equilibrium, low-pressure conditions. Copper shows enrichments greater than those expected for equilibrium Rayleigh fractionation; the excess copper is probably derived from sulfides lining the walls of the original vesicles. The segregations are produced by the mobilization and injection of residual melt driven by overpressures developed during crystallization and vesiculation, after the flow has developed a rigid crystal framework.

\section{ACKNOWLEDGMENTS}

I would like to thank the crew, technicians, and drillers aboard the JOIDES Resolution for their outstanding work in obtaining the Leg
135 samples. Shawn Dolan and Jennifer Chase provided critical assistance with the geochemical analyses. Reviews by James Hawkins, James Natland, and Peter Meyer greatly improved the manuscript. This work was supported by a grant from JOI-USSAC.

\section{REFERENCES}

Allegré, C.J., Treuil, M., Minster, J., Minster, B., and Albarede, F., 1977. Systematic use of trace elements in igneous processes, Part I: fractional crystallization processes in volcanic suites. Contrib. Mineral. Petrol., 60:57-75.

Anderson, A.T., Jr., Swihart, G.H., Artioli, G., and Geiger, C.A., 1984. Segregation vesicles, gas-filter-pressing, and igneous differentiation. J. Geol.. 92:55-72.

Baragar, W.R.A., Plant, A.G., Pringle, G.J., and Schau, M., 1977. Petrology and alteration of selected units of Mid-Atlantic Ridge basalts sampled from Sites 332 and 335. DSDP. Can. J. Earth Sci., 14:837-874.

Bloomer, S.H., Meyer, P.S., Dick, H.J.B., Ozawa, K., and Natland, J.H., 1991. Textural and mineralogical variations in gabbroic rocks from Hole 735B. In Von Herzen, R.P., Robinson, P.T., et al., Proc. ODP, Sci. Results, 118: College Station, TX (Ocean Drilling Program), $21-40$.

Dick, H.J.B., 1980. Vesicularity of Shikoku Basin basalt: a possible correlation with the anomalous depth of back-arc basins. In Klein, G. deV., Kobayashi, K., et al., Init. Repts. DSDP, 58: Washington (U.S. Govt. Printing Office), 895-904.

Elthon, D., 1983. Isomolar and isostructural pseudo-liquidus phase diagrams for oceanic basalts. Am. Mineral., 68:506-511.

Garcia, M.O., Liu, N.W.K., and Muenow, D.W., 1979. Volatiles in submarine volcanic rocks from the Mariana Island arc and trough. Geochim. Cosmochim. Acta, 43:305-312.

Grove, T.L., 1990. Cooling histories of lavas from Serocki Volcano. In Detrick, R., Honnorez, J., Bryan, W.B., Juteau, T., et al., Proc. ODP, Sci. Results, 106/109: College Station, TX (Ocean Drilling Program), 3-8.

Kuno, H., 1965. Fractionation trends of basalt magmas in lava flows. J. Petrol., $6: 302-321$

Kuno, H., Yamasaki, K., Iida, C., and Nagashima, K., 1957. Differentiation of Hawaiian magmas. Jpn. J. Geol. Geog., 28:179-218.

MacPherson, G.J.. 1984. A model for predicting the volumes of vesicles in submarine basalts. J. Geol., 92:73-82.

Parson, L., Hawkins, J., Allan, J., et al., 1992. Proc. ODP, Init. Repts., 135: College Station, TX (Ocean Drilling Program).

Philpotts, A.R., 1982. Compositions of immiscible liquids in volcanic rocks. Contrib. Mineral. Petrol., 80:201-218.

1990. Principles of Igneous and Metamorphic Petrology: Englewood Cliffs. NJ (Prentice Hall).

Sarda, P., and Graham, D., 1990. Mid-ocean ridge popping rocks: implications for degassing at ridge crests. Earth Planet. Sci. Let1., 97:268-289.

Sato, H., 1979. Segregation vesicles and immiscible liquid droplets in oceanfloor basalt of Hole 396B, IPOD/DSDP Leg 46. In Dmitriev, L., Heirtzler, J., et al., Init. Repts. DSDP, 46: Washington (U.S. Govt. Printing Office), 283-297.

Shibata, T., DeLong. S.E., and Walker, D., 1979. Abyssal tholeiites from the Oceanographer Fracture Zone. I. Petrology and fractionation. Contrib. Mineral. Petrol., 70:89-102.

Shipboard Scientific Party, 1988. Site 648. In Detrick, R., Honnorez, J., et al., Proc. ODP, Init. Repts., 106/109: College Station, TX (Ocean Drilling Program), 35-134.

1990. Site 793. In Taylor, B., Fujioka, K., et al., Proc. ODP, Init. Repts., 126: College Station, TX (Ocean Drilling Program), 315-403.

Smith. R.E., 1968. Segregation vesicles in basaltic lava. Am. J. Sci., 265:696713.

Yeats, R.S., and Mathez, E.A., 1976. Decorated vesicles in deep-sea basalt glass, eastern Pacific. J. Geophys. Res., 81:4277-4284.

Abbreviations for names of organizations and publication titles in ODP reference lists follow the style given in Chemical Abstracts Service Source Index (published by American Chemical Society).

Date of initial receipt: 22 June 1992

Date of acceptance: 7 June 1993

Ms 135SR-127 